\title{
The Arabic Lexicographer Ibn Sīdah and the Notion of Semantic Field
}

\author{
FRANCESCO GRANDE (Venezia, Università Ca’ Foscari)
}

\begin{abstract}
Etymological investigation may resort to the semantic field in order to obtain a deeper understanding of the cultural aspects that underlie the origin and historical development of a given word. Modern scholars tend to regard the semantic field as a notion developed in Western linguistic thought around the mid-nineteenth and early twentieth century. However, Arabists tend to assume that this notion was already known in the Arabic lexicographical tradition. The present paper empirically grounds this idea in three conceptual steps. First, it clarifies the modern Western notion of semantic field by investigating the theoretical contexts in which such a notion evolved, morphing into different manifestations. Second, it focuses on the dictionaries al-Muhkam and al-Mukhașsas authored by the Andalusian lexicographer Ibn Sīdah (d. 458/1066) and offers a close reading of some of the passages in which Ibn Sīdah reflects on the notion of $b \bar{a} b$. Finally, it draws a narrow parallel between $b \bar{a} b$ and a mid-nineteenth-century manifestation of the Western notion of semantic field.
\end{abstract}

Key words: bāb, Ibn Sīdah, lexicography, semantic field

\section{Introduction}

Etymology is the investigation of the origin of a given word, of its historical vicissitudes, as well as of the phonological and semantic changes undergone through them. ${ }^{1}$ Etymological investigation may also pave the way to a deeper understanding of the cultural setting in which the investigated word originated and evolved, especially if the domain of inquiry is broadened to encompass other words that share with the investigated word the reference to a socio-cultural aspect of human life (Lebensform). ${ }^{2}$

For instance, an overall study of the etymology of the Mesopotamian theonyms Ālum, Apsum, Ishum, Nārum, and Padan reveals not only that they originally meant 'city', 'ocean', 'fire', 'river', and 'path', respectively, but also that, taken as a whole, they all probably point to a social process of sedentarization by Semitic nomadic groups in Mesopotamia. $^{3}$

1 See, e.g., MALKIEL 1993: 109.

2 As remarked by PISANI 1938: 10, 40-2.

3 Cf. Moscati 1958: 133-4.

Journal of Arabic and Islamic Studies • 17 (2017): 415-433 (C) Francesco Grande, University of Venice Ca' Foscari, Venice / Italy 
Linguists usually associate the common reference of several words with a Lebensform and, more generally, with a major concept such as a semantic field. Given the importance of this linguistic concept for culturally-oriented etymological studies, as has just been illustrated, the present paper will provide a thorough epistemological discussion of it, informed by an Arabistic approach. In fact, it will take into account the manifestation of the concept in the Arabic lexicographical tradition, particularly in the lexicographical work of Ibn Sīdah (d. 458/1066), in addition to the manifestations of this linguistic phenomenon in Western linguistics.

\section{The Notion of semantic field in Western linguistic thought}

The first known attestation of the technical term 'semantic field' dates to 1924, when the Indo-Europeanist Gunther Ipsen coined the compound Bedeutungsfeld in his paper Der alte Orient und die Indogermanen. ${ }^{4}$ At the core of this German compound is the felicitous metaphor of the field $(-f e l d)$, which conveys the notion of a group of elements of semantic nature (Bedeutung-). ${ }^{5}$ Ipsen fine-tuned this notion by means of the following definition: a Bedeutungsfeld is obtained when a given word or lexeme is associated with another like the pieces in a mosaic, ("die ganze Gruppe ein «Bedeutungsfeld» absteckt [...]; wie in einem Mosaik fügt sich hier Wort an Wort") and both of them refer to one and same major concept ("alle zusammen in einer Sinneinheit höherer Ordnung"). ${ }^{6}$ Ipsen's definition provides the descriptive basis for the recognition of a semantic field in the present paper: the semantic field is a linguistic entity that groups together two or more words on the basis of their semantic reference to a major concept.

However, Ipsen only touched very briefly upon the notion of semantic field in his paper, providing no fully-fledged examples or case-studies, except for the cursory mention of the two semantic fields of sheep raising and metal in some Indo-European languages. ${ }^{7} \mathrm{By}$ contrast, the Germanist Jost Trier devoted his entire monograph Der Deutsche Wortschatz im Sinnbezirk des Verstandes ${ }^{8}$ to the notion of semantic field, which has led some scholars to credit him, rather than Gunther Ipsen as the real founder of this notion. ${ }^{9}$ In his monograph, published in 1931, a few years after Ipsen's paper, Trier concretely investigated many sets of German lexemes related to intellectual life, such as the lexical set referring to the German system of school marks (Leistungsbewertung), ${ }^{10}$ and gave a more nuanced

\footnotetext{
4 IPSEN 1924: 225, CLARKE \& NERLICH 2000: 133.

5 A similar expression, based on the same metaphorical process, is found in hard sciences, e.g., Magnetfeld The possible epistemological link between Bedeutungsfeld and Magnetfeld etc. will not be further explored here. See CLARKE \& NERLICH 2000: 139 for further details.

6 IPSEN 1924: 225.

7 IPSEN 1924: 224.

8 TRIER 1931.

9 See, e.g., GEERAERTS 2010: 53-4.

10 TRIER 1931: 47. Cf. also ClARKE \& NERLICH 2000: 135-6.
} 
formulation of the notion of semantic field by decomposing it into a lexical field (Wortfeld) and a conceptual field (Begriffsfeld). ${ }^{11}$

Apart from these empirical and theoretical details, Trier is largely indebted to Ipsen for the notion of semantic field, since he shares with his predecessor the 'visual' representation of this notion in terms of a mosaic, as is easily gleaned from a simple intertextual comparison between Ipsen's definition of semantic field, as summarized immediately above, and Trier's: "Die Stelle an der es [i.e., a word], von ihnen umdrängt, in dem grossen Mosaik des Zeichenmantels als kleiner Stein sitzt, entscheidet über seinen Gehalt". ${ }^{12}$ Recent intertextual research therefore reveals the presence of new technical terminology (Bedeutungsfeld and the related terms Wortfeld, Begriffsfeld) as well as of definitions in Ipsen's and Trier's studies, which make it possible to ascribe the codification of the notion of semantic field to both scholars. ${ }^{13}$

Furthermore, recent intertextual research has revealed that the codification of the notion of semantic field on the part of Ipsen and Trier is the result of a long process of theoretical reflection, the roots of which reach back to about a century before Ipsen's and Trier's work. By way of illustration, Ipsen and Trier derive their notion of semantic field in part from the notion of inner linguistic form (innere Sprachform), first formulated by Wilhelm von Humboldt in $1836 .{ }^{14}$ In greater detail, Ipsen remarks that his notion of semantic field is intrinsically holistic in that it consciously avoids the semantic investigation of words in isolation: "ferner die eigenwörter stehn in einen sprache nie allein sondern sind eingeordnet in Bedeutungsgruppen" ${ }^{15}$ Trier too subscribes to a holistic notion of semantic field when he maintains that "No spoken word is as isolated in the consciousness of the speaker and the hearer as one might conclude from its phonetic isolation." ${ }^{16}$ Moreover, according to Trier, the empirical basis of the holistic nature of the semantic field is, inter alia, the fact that virtually any word implies a word of opposite meaning (antonymy or Gegensinn): "Every spoken word calls forth its opposite sense." ${ }^{17}$ In later work, Trier himself recognizes that he draws the notion of semantic field thus characterized from the semantic studies carried out by the Egyptologist Karl Abel at the end of the nineteenth century ${ }^{18}$ However, Abel is responsible only for singling out antonymy as an empirical basis for the notion of semantic field, whereas he is aware of the holistic nature of this notion because of his interest in Humboldtian thoughts about inner linguistic form. The gist of the Humboldtian notion of inner linguistic form is that while two languages can incidentally express a given

11 TRIER 1931: 3ff., 40ff. Cf. also ClARKE \& NERLICH 2000: 134-5.

12 TRIER 1931: 3. Cf. also GEERAERTS 2010: 54.

13 On the coinage of new technical terms and/or definitions as epistemological criteria of a stage of theoretical codification in modern Western science, see PELED 1999: 54. The codification of the notion of semantic field foreshadows a subsequent proliferation of technical terminology and definitions, such as lexical field, conceptual field, word field, etc. Cf. GEERAERTS 2010: 56.

14 Humboldt 1836: 84-86, 91-103. Cf. also GEeRAERTS 2010: 18.

15 IPSEN 1924: 225.

16 TRIER 1931: 1. English translation by CLARKE \& NERLICH 2000: 130.

17 TRIER 1931: 1. English translation by CLARKE \& NERLICH 2000: 130.

18 Cf. ClARKE \& NERLiCH 2000: 129-30. 
meaning in the same manner, they will never be identical when expressing a given complex of meanings, as is shown by the expression of the color spectrum, which typically varies from one language to another. ${ }^{19}$ This applies even more if we look into the entire complex of meanings they express: their inner linguistic form. It follows, according to Humboldt, that the real understanding of a given language's semantics proceeds from the investigation of its holistic nature (inner linguistic form) rather than from an atomistic approach, which tries to find the meanings of single words. ${ }^{20}$

This brief intertextual overview reveals that the interpretation alluded to above, according to which the older notion of inner linguistic form is the ancestor of the modern notion of semantic field, is empirically grounded in the essential feature shared by both notions, namely the holistic nature of meaning. ${ }^{21}$ Furthermore, recent intertextual research traces two other essential features of the semantic field back to inner linguistic form: the negative nature and cultural relevance of meaning. The negative nature of meaning is a sort of corollary of its holistic nature. Not only Trier and Ipsen, but also Humboldt are aware that if the meaning of a given word can only really be understood by means of (an)other word(s) rather than in isolation, no word meaning can be posited independently of others, i.e., no positive word meaning pre-exists that complex of word meanings conceived by Humboldt as an inner linguistic form and, later on, by Ipsen and Trier as a semantic field. ${ }^{22}$

Also the cultural relevance of meaning is an essential feature of the notion of inner linguistic form prior to that of semantic field. The very titles of the works in which Humboldt, Ipsen and Trier introduce the notions of inner linguistic form or semantic fields testify to the cultural relevance they ascribed to these notions, be it related to material or intellectual culture: Über die Verschiedenheit des menschlichen Sprachbaues und ihren Einfluss auf die geistige Entwickelung des Menschengeschlechts, Der alte Orient und die Indogermanen, Der deutsche Wortschatz im Sinnbezirk des Verstandes: Die Geschichte eines sprachlichen Feldes I: Von den Anfüngen bis zum Beginn des 13. Jhdts., respectively. The cultural relevance of meaning, not unlike the negative nature of meaning, is deeply interlocked with its holistic nature. Effectively, the ultimate aim lying behind the investigation of meaning as a whole is to gain insight into the material or intellectual culture referred to (whereas the same aim could hardly be attained through the investigation of a single piece of meaning, e.g., an isolated word). ${ }^{23}$

In this theoretical scenario, the notions of semantic field and inner linguistic form are both characterized by two purely linguistic features, namely the holistic and negative nature of meaning, which are actually upon closer scrutiny a particular instance of a more general phenomenon. In present-day linguistics, the holistic and negative nature can be defining features of any linguistic complex which, technically speaking, qualifies as a structure. This state of affairs has recently led some scholars to interpret the semantic field and its ances-

\footnotetext{
19 ANTTILA 1989: 9-11.

20 Clarke \& NerLich 2000: 128-9, GeERAERTS 2010: 18-9.

21 Clarke \& Nerlich 2000: 126.

22 GEERAERTS 2010: 51.

23 Clarke \& Nerlich 2000: 129, GeERAerts 2010: 19.
} 
tor, i.e., the inner linguistic form, as a semantic structure. ${ }^{24}$ This structuralist interpretation should be accepted cum grano salis, provided that it does not deny the notion of semantic field and its ancestor, i.e., the notion of linguistic form, the original context of linguistic reasoning they developed out of, which we can identify with the so-called comparative method. Humboldt himself provides an interesting clue to determining the comparative method as the theoretical context of the notion of semantic field, when he offers a casestudy in inner linguistic form, which relies upon data collected by the Indo-Europeanist Franz Bopp, namely the Sanskrit and Ancient Greek infinitives. ${ }^{25}$ At this point, in order to understand the original theoretical context of the notion of semantic field and of its ancestor, i.e., the inner linguistic form, a brief illustration of the comparative method is in order.

\section{Semantic field and comparative method}

In his comprehensive study on the subject of comparative method, Anttila defines it as follows: "comparative linguistics has two tasks: establishing the fact and degree of relationship for two or more languages [...] and reconstructing earlier (prehistoric) stages, called protolanguages". ${ }^{26}$ According to Anttila's definition, the comparative method is reducible to two more primitive theoretical ingredients: the comparison proper of two or more languages, and their historical investigation. Once the comparison of two or more languages is explicitly distinguished from an investigation into their history, it becomes desirable to re-conceptualize (and re-label) the comparative method as a 'historicalcomparative' method or, alternatively, to dismiss the terms 'comparison, comparative', which a long scholarly tradition has uncorrectly burdened with historical implications, in favor of the more neutral terms 'syncrisis, syncritical': "A serious terminological difficulty has arisen from the fact that genetic linguistics has preempted the term 'comparative'. [...] Sometimes the words 'typological' or 'contrastive' serve this purpose (nonhistorical comparison), but often they are not inclusive enough. The Greek counterpart to 'contrast' and 'comparison', syncrisis, has been proposed for this task. Others, in order to avoid confusion, use the compound 'historical-comparative' for the highly technical notion of 'comparative' in genetic linguistics". ${ }^{27}$

Anttila's bipartite definition of the (historical)-comparative method has a bearing on the definition of its object, which also becomes bipartite. The object of historical investigation is change ("historical linguistics treats changes of various kinds") ${ }^{28}$ whereas the object of comparison, or syncrisis, is variation ("syncrisis is a generic aspect of the study of varia-

24 See, e.g., GEERAERTS 2010: 51.

25 HumboldT 1836: 93.

26 ANTTILA 1989: 20. Later in his monograph, ANTTILA 1989:318 reiterates the same definition of comparative method: "another division in comparative linguistics: (1) determination of fact and degree of relationship and (2) reconstruction of earlier stages."

27 ANTTILA 1989: 20

28 ANTTILA 1989: 19. 
tion"), ${ }^{29}$ and especially the kind of variation manifested by two or more languages, e.g., within a language family. Another important kind of variation is the one manifested by a single language, in the form of different dialects, situations etc. ("there is even more variation between two speakers, and so on, until we reach the whole language, or even a language family"). ${ }^{30}$ Developing Anttila's terminology, which defines the kind of variation manifested by a single language as intralinguistic ${ }^{31}$ we will refer here to the kind of variation manifested by two or more languages, which is the proper subject of investigation of the historical-comparative method, as interlinguistic.

On these grounds, a balanced analysis of the notions of semantic field and inner linguistic form should highlight their features-such as aspects of interlinguistic variation and change-building on the historical-comparative method, in addition to the features related to structuralism, such as the holistic and negative nature of meaning (cf. the previous section). It is instructive in this respect that Ipsen subsumes under the semantic field of metal (Metalle $)^{32}$ nouns meaning 'silver', 'copper', 'axe', which are attested in several IndoEuropean languages (interlinguistic variation) and take on different phonetic forms in time (change) ${ }^{33}$ Similarly, the Trierian semantic field aims at capturing the evolution of the terminology for mental properties from Old High German up to the beginning of the thirteenth century (change): Trier makes this aim clear right from the very title of his book: Der deutsche Wortschatz im Sinnbezirk des Verstandes: Die Geschichte eines sprachlichen Feldes I. Von den Anfüngen bis zum Beginn des 13. Jhdts. ${ }^{34}$

Finally Humboldt, in his discussion of inner linguistic form, compares the different ways in which Sanskrit and Ancient Greek express the infinitive (interlinguistic variation) and asserts that the expression of infinitive in the former language is less developed than its expression in the latter (change). ${ }^{35}$

In sum, the long process of theoretical reflection that we have outlined in the previous section shapes a notion of semantic field that qualifies as semantically holistic and semantically negative from a structuralist perspective; as diachronic and interlinguistic from a historical-comparative perspective; and as culture-oriented. A major stage in this process of theoretical reflection is the formulation of the notion of inner linguistic form: intertextual evidence supports an interpretation of this notion, which considers it to be the ancestor of the notion of semantic field. However, this is not the whole story. The long process of theoretical reflection to which Humboldt, Ipsen and Trier made key contributions is not the only factor responsible for the emergence of the notion of semantic field, another decisive factor being the practical work of lexicographers, especially in the domain of stylistics. The next section addresses this issue.

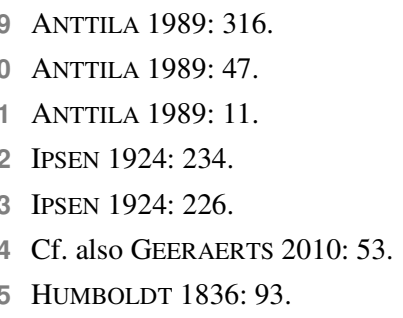




\section{Semantic field and stylistics}

According to some linguists, the notion of semantic field originates in nineteenth-century lexicography, which placed particular emphasis on matters of style, such as synonymy and antonymy. ${ }^{36}$ This interpretation finds its raison d'être in the peculiar arrangement informing a dictionary with stylistic purposes, known as the Thesaurus of English Words and Phrases, Classified and Arranged so as to Facilitate the Expression of Ideas and Assist in Literary Compositions and published by Peter Mark Roget in $1852 .{ }^{37}$ Roget establishes six major ideas on a conceptual level then arranges the English words exhibiting a meaning related to one of these ideas into a group, labeling this kind of word 'correlative', and the group a 'class'. It was precisely the tendency of Roget's class to group two or more words together on the basis of their semantic reference to a major concept that allows it to be assimilated to the modern notion of semantic field in the first instance (cf. the definition of Bedeutungsfeld at the beginning of this paper). In Roget's own words: "The idea being given, to find the word, or words, by which that idea may be most fitly and aptly expressed. For this purpose, the words and phrases of the language are here classed, not according to their sound or their ortography, but strictly according to their signification,"38 "Commencing with the idea expressing abstract relations, I proceed to those which relate to space and phenomena of the material world, and lastly to those in which the mind is concerned [...] thus establishing six primary Classes of Categories," 39 "the whole group of correlative words." 40

More accurately, the Rogetian notion of class can be assimilated to Ipsen's notion of Bedeutungsfeld because of two specific features. On the one hand, the notion of class avoids as far as possible considering words in isolation and, to this aim, also includes words with the opposite meaning to the major idea conveyed ("There exist comparatively few words of a general character to which no correlative term, either of negation or of opposition, can be assigned"). ${ }^{41}$ This feature of Roget's notion of class is in essence identical to the holistic nature of meaning, which is a key feature of Ipsen's notion of Bedeutungsfeld. On the other hand, Roget remarks that "The study of correlative terms existing in a particular language may often throw valuable light on the manners and customs of the nations using it, ${ }^{42}$ thereby clarifying the cultural implications of the notion of

36 See, e.g., ClARKE \& NERLICH 2000: 128. Not all linguists are sympathetic to this interpretation, since the notion of semantic field formulated within the context of stylistics-oriented lexicography crucially lacks one of the two epistemological criteria determining a realistic stage of codification in modern Western science, i.e., the coinage of a new technical term: cf. the beginning of the first section and references therein. For instance, GEERAERTS 2010 makes no mention of Roget's Thesaurus in his review of the many manifestations of the notion of semantic field.

37 See HÜLLEN 2003 for a comprehensive recent study on Roget's Thesaurus.

38 ROGET 1852: xiii.

39 Roget 1852: xvii.

40 RoGET 1852: xiv.

41 Roget 1852: xxii.

42 Roget 1852: xix. 
class ("correlative terms"), which to a great extent correspond to the feature of cultural relevance typical, again, of Ipsen's notion of Bedeutungsfeld.

But the parallel between the Rogetian notion of class and Ipsen's notion of Bedeutungsfeld cannot be extended further. In fact, the Rogetian notion of class, albeit also useful for cultural purposes, as illustrated immediately above, pursues primarily stylistic purposes, such as the retrieval of synonyms or antonyms. This is shown by the presentational design of the notion of class: whenever possible, Roget divides the words belonging to it into two columns, one of which lists the synonyms and the other the antonyms. Roget clearly states this point as follows:

For the purpose of exhibiting with greater distinctness the relations between words expressing opposite and correlative ideas, I have, whenever the subject admitted of such an arrangement, placed them in two parallel columns in the same page, so that each group of expressions may be readily contrasted with those which occupy the adjacent column, and constitute their antitheses. By carrying the eye from the one to the other, the inquirer may often discover forms of expression of which he may avail himself advantageously to diversify and infuse vigour into his phraseology. Rhetoricians, indeed, are well aware of the power derived from the skilful introduction of antitheses in giving point to an argument, and imparting force and brilliancy to the diction. ${ }^{43}$

In this sense, the Rogetian notion of class is stylistics-oriented, whereas Ipsen's notion of Bedeutungsfeld and the like are not.

Furthermore, Roget remarks that his work only describes the variety of English in use at his time ("Words which have, in process of time, become obsolete, are of course rejected from this collection" ${ }^{44}$ ), thus implicitly characterizing the notion of class as intralinguistic and synchronic, in sharp contrast to the interlinguistic and diachronic nature of Ipsen's notion of Bedeutungsfeld and the like. Last but not least, when Roget makes interchangeable use of the technical terms 'idea' and 'signification' ("its signification, or the idea it is intended to convey" 45 ) or when he asserts that "such classification of ideas is the true basis on which words, which are their symbols, should be classified," ${ }^{46}$ he follows a long-standing tradition of philosophical and linguistic thought, which considers word meanings merely as linguistic reflexes of pre-existing ideas. This is tantamount to saying that the positive nature of meaning is a fundamental feature of Roget's notion of class, which neatly distinguishes it from the Ipsenian notion of Bedeutungsfeld, founded instead on the negative nature of meaning, as shown in the previous sections. The similarities (in italics) and differences between Roget's class and Ipsen's Bedeutungsfeld and the like are schematized in Table 1 (see next page).

43 Roget 1852: xix.

44 Roget 1852: xxvi.

45 ROGET 1852: xiii.

46 ROGET 1852: xxxviii.

jais • 17 (2017): 415-433 


\begin{tabular}{lll}
\hline Version & 'Historical-comparative' & 'Stylistic' \\
Example & Innere Sprachform, Bedeutungsfeld & Class \\
Main proponent(s) & Humboldt, Ipsen, Trier & Roget \\
Features & Semantically holistic & Semantically holistic \\
& Semantically negative & Semantically positive \\
& Interlinguistic & Intralinguistic \\
& Diachronic & Synchronic \\
& Culture-oriented & Culture-oriented \\
& - & Stylistics-oriented \\
\hline
\end{tabular}

Table 1 - The Notion of Semantic Field and Its Features

Roget himself acknowledges that in developing his "systematic arrangement of Ideas, " ${ }^{47}$ he drew inspiration from a long-standing tradition of philosophical and linguistic thought, which began as early as the late fourth century CE, when the Sanskrit lexicographer Amarasimha authored the Amarakośa, a thesaurus that organizes the Sanskrit words according to general themes such as divinities, natural elements, etc. The influence that Sanskrit lexicography exerted on Roget's thesaurus widens the perspective of our epistemological investigation concerning the notion of semantic field in lexicographical traditions other than the Western one. In this spirit, the remainder of the present paper will explore the possibility that the Arabic lexicographical tradition was aware of such a notion. Before proceeding further, however, a word of caution is needed: as discussed at length in the previous sections, the Western notion of semantic field grew out of two different linguistic approaches, manifesting itself in two different versions.

The former, which is deeply interlocked with the (historical-) comparative method and will accordingly be referred to here as the 'historical-comparative version' of the notion of semantic field, is exemplified by Ipsen's Bedeutungsfeld. The latter, which is deeply interlocked with the nineteenth-century lexicography focused on stylistics and which will, for the sake of convenience, be referred to here as the 'stylistic version' of the notion of semantic field, is exemplified by Roget's class. The bipartite manifestation of the modern Western notion of semantic field is summarized in Table 1. It is important to bear this in mind in the following investigation of a possible manifestation of the notion of semantic field within the context of Arabic lexicographical tradition.

\section{Semantic field and Arabic lexicographical tradition}

In their reference works on Arabic lexicographical tradition, Haywood and Baalbaki find the equivalent of the notion of semantic field in many thesauri authored by renowned lexi-

47 Roget 1852: xxviii (capital "I" is Roget's). 
cographers, such as al-Așma'ī (d. 216/831) and Ibn Sīdah (d. 458/1066), to mention but a few. ${ }^{48}$ In his studies specifically devoted to Ibn Sīdah's life and work, Cabanelas takes an analogous position. ${ }^{49}$ These scholars all observe that the two fundamental compositive units of these thesauri, notably the kitāb 'book' and the $b \bar{a} b$ 'chapter', actually group several words, which all refer to a major concept. For instance, the early Arabic lexicographer Abū Zayd al-Anșārī (d. 215/830) groups the two words 'iḍāh 'great thorny trees' and shirs 'small thorny trees' into a kitāb dealing with the asmä' al-shajar, 'the names of trees'. Because of this semantic condition, as illustrated at the beginning of the present paper, Haywood, Cabanelas and Baalbaki all hold that the kitāb and $b \bar{a} b$ found in the traditional thesauri of Arabic can be likened to the modern Western notion of semantic field. ${ }^{51}$

That said, this valuable interpretation requires further elaboration, as it is seemingly saddled with two epistemological drawbacks. The first epistemological drawback is that a compositive unit is not a fully-fledged notion. ${ }^{52}$ The practical task of grouping two or more words on the basis of their semantic reference to a major concept may not have necessarily been the object of theoretical reflection on the part of the Arabic lexicographers. Even conceding that an intuitive perception of the semantic field informs the thesauri authored by them, the fact still remains that an intuition of this sort does not automatically result in their awareness of the semantic field in the form of a real notion. On a constructive note, according to Owens the stable designation of a fixed class of items throughout time, e.g., from one generation of grammarians and lexicographers to another, is considerable evidence for the existence of a self-aware notion in Arabic linguistic tradition. ${ }^{53}$ In the case of the possible manifestation of the notion of semantic field within the context of Arabic lexicographical tradition, Owens' argument can be construed as follows. First, two or more words arranged into a group on the basis of their semantic reference to a major concept can be intended epistemologically as a fixed class of items. Second, the terms $b \bar{a} b$ and kitāa indeed signify a group of this kind. Third, they will qualify as manifestations of the notion of semantic field if it can be proven that either term was circulated with this exact meaning by several generations of Arabic lexicographers.

The second epistemological drawback is that the terms $b \bar{a} b$ and kitāb do not unambiguously mean 'semantic field', which may be considered a specific technical interpretation of $b \bar{a} b$ and kitāb co-existing with their general sense of 'chapter' and 'book', respectively, so in principle Arabic lexicographers may have used these words in their general sense rather than in their specific technical sense. The researcher is thus confronted with a situation of interpretive ambiguity arising from the lack of a clear-cut differentiation between a specific

48 See the following footnotes for detailed references.

49 See, e.g., CABAnElas 1961: 132. Cf. also the Introduction by al-Ṭ̂ALIBĪ 1956 to his alphabeticallyarranged index of the bābs of the Mukhașṣaș.

50 BAALBAKI 2014: 137.

51 BAAlBAKI 2014: 132, 199, 205, 276, 323, 329, 343, 353. Cf. also CABANELAS 1961: 27 and HAYWOOD 1960: 43, who uses the expression 'restricted vocabulary area'.

52 This is why BAALBAKI 2014: 199 cautiously sometimes translates $b \bar{a} b$ as 'semantic field' and sometimes as 'thematically arranged chapter'. Cf. also HAYWOOD 1960: 65, who renders the same term not only as 'restricted vocabulary area', but also as 'subject heading'.

53 OWENS 1990: 11. Cf. also PELED 1999: 55.

jais • 17 (2017): 415-433 
technical sense and a general sense, which according to Peled is not confined to $b \bar{a} b$ and $k i t a \bar{b}$, but widespread throughout the entire technical terminology of Arabic linguistic tradition. ${ }^{54}$ The ultimate cause of this interpretive ambiguity is the fact that the Arabic grammarians and lexicographers were not inclined to coin new terms for the grammatical and lexicographical notions they introduced in their treatises and dictionaries, preferring instead to link these technical notions to words already in use with a general sense. A simple criterion has been proposed in the literature to determine whether, in the absence of a clear definition, a given Arabic term conveys a general sense, or has been assigned a new, specific technical meaning linked to a grammatical or lexicographical notion: the presence of a metalinguistic discussion, such as an intellectual controversy, about the term in question, or lack thereof. ${ }^{55}$ In this light, the traces of a controversy among the Arabic lexicographers concerning the ability of the term $b \bar{a} b$ and kitāb to group two or more words on the basis of their semantic reference to a major concept can support an interpretation that assimilates either term to the modern notion of semantic field. To summarize, for the term $b \bar{a} b$ and $k i t a \bar{b}$ to be construed as a notion akin to that of semantic field, it must convey the sense of a group of two or more words all referring to a major concept, a sense which is at once intergenerational and subject to an intellectual controversy in the Arabic lexicographical tradition.

The next section discusses both these aspects with particular reference to the term $b \bar{a} b$ as used by the Andalusian lexicographer Ibn Sīdah in his two dictionaries al-Muhkam and al-Mukhașsas. As known to modern scholars, in fact, in his introductions to these works Ibn Sīdah embarks on metalinguistic discussions of a lexicographical nature, which involve, inter alia, two terms etymologically related to $b \bar{a} b$, i.e., mubawwab 'a dictionary arranged into $b \bar{a} b s$ ', and $t a b w \bar{\imath} b$, i.e., 'the arrangement of a dictionary into $b \bar{a} b s$ ' ${ }^{56}$ Consequently, these introductions constitute a promising domain of inquiry for a possible interpretation of the term $b \bar{a} b$ along the lines of the modern Western notion of semantic field.

\section{The notion of semantic field in Ibn Sīdah's linguistic thought}

Ibn Sīdah is traditionally recognized as the author of two dictionaries, entitled al-Muhkam and al-Mukhașșaṣ deliberately arranging virtually the same lexical material ${ }^{57}$ according to two different criteria: in the Muhkam he adopts a peculiar alphabetical order inspired by the phonetic-permutative system of al-Khalīl (d. 175/791) to present the lexical material; ${ }^{58}$ whereas in the Mukhașsas he resorts to a thematic criterion to this effect. ${ }^{59}$ It is precisely the thematic criterion adopted by Ibn Sīdah in the Mukhașsas that shapes the latter into the compositive units $b \bar{a} b$ and kitāb introduced in the previous section. In all likelihood, Ibn

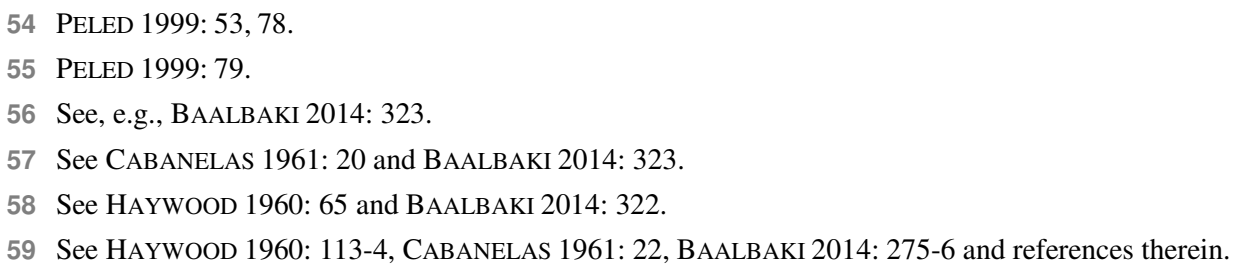


Sīdah authored both dictionaries simultaneously, which explains why in his Introduction to the Muhkam he sometimes alludes to the Mukhașșas and vice versa. ${ }^{60}$ Keeping this in mind, we can now turn our attention to the introductions to these dictionaries and to the passages which can justify an interpretation of $b \bar{a} b$ as a notion akin to that of semantic field. To begin with, let us consider the following passage, drawn from the Muhkam:

Among the features of this dictionary is [...] the preservation of a huge amount of meanings, but expressed in a simple fashion. In fact, [what I found] in the dictionaries of other lexicographers [is that] many times they were verbose when writing a $b \bar{a} b$, so as to assign a given attribute of this $[b \bar{a} b]$ to many species, whereas I assigned it to a genus [overarching the species]; in this manner I dispensed with mentioning specific cases, mentioning the general case only. Indeed, if a given attribute is assigned to an animal, it is automatically assigned to a lion, a horse or a man, and to any other species that turns out to have the animal as its genus. In consequence of this, what has been written in many lines in the dictionaries of other lexicographers is often condensed into one line in my dictionary. To state it briefly: as fragmented as they can be, the $b \bar{a} b$ s posited by other lexicographers can be reduced to my $b \bar{a} b$ s. For instance, Abū 'Ubayd said: [...] dha'ānīn is a plant and tarāthīth is a plant; in the singular: dhu'nūn, țurthüth. The Arabs say yatadha'nanūna, yatațarthathūna when the people go out in search of these plants. But I dispense with all of this information, which is of much hindrance and of little efficacy, and I simply say under the letter $d h$ : dhu'nūn is a plant; and under the letter $t:$ turthüth is a plant, since the singular referent, when expressed by [the pattern] $f u^{\prime} l \bar{u} l$, must take on the plural [pattern] $f a^{c} \bar{a} l \bar{l} l$ - whereas [the opposite is not true, as] the plural $f a^{c} \bar{a} l \bar{l} l$ must not

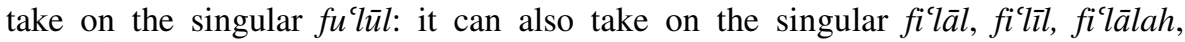
ficīlah. ${ }^{61}$

A key factor to understanding this passage is the parallel that the Andalusian lexicographer draws between the term $b \bar{a} b$ and the philosophical taxonomical term jins, i.e., the genus. According to this parallel, the $b \bar{a} b$, which Ibn Sīdah exemplifies as a plural pattern $f a \bar{a} l \bar{l} l$, behaves as the genus, e.g., animal; the plural words dha'ānīn, țarāthīth behave as the at-

60 See Cabanelas 1961:20 and BAALbaKi 2014: 323. Cf. also Haywood 1960: 65, 113 for a different dating hypothesis.

61 IBN SĪDAH, Muhkam, i: 37-8. The original text reads: mā tahallà bi-hi min-a [...] 'l-muhäfazati 'alà jam'i 'l-ma'ān̄̄ 'l-kathīrati fī 'l-alfāzi 'l-yasìrati fa-kam bābin fì kutubi ahli 'l-lughati ațālū-hu bi-an akhadhū mahmmūla-hu [i.e., al-bābi] 'alà anwā'in jammatin wa-akhadhtu-hū anā 'alà 'l-jinsi faghanaytu 'an dhikri 'l-furūi i bi-dhikri 'l-jinsi fa-inna-hū idhā kāna 'l-mahmūlu ma'khūdhan 'alà 'lhayawāni fa-lā mahāalata anna-hū ma'khüdhun 'alà 'l-sabu'i wa'l-farasi wa'l-insāni wa-ghayri dhālika min-a 'l-anwā' $i$ 'llatī najidu 'l-hayawāna la-hā jinsan fa-rubba satrin min kitābī yaghtarifu min kutubi ahli 'l-lughati fì 'l-khatți suțūran fa-idhā hușșila jawharu 'l-kalāmi 'ādat abwābuhum li-abwābì shuțūran ka-qawli abū 'ubayd al-dha'ānīnu nabatun wa'l-tarāthīthu nabatun al-wähidu dhu'nūn waturthūth wa-yuqālu kharaja 'l-nāsu yatadha'nanūna wa-yatațarthathūna idhā kharajū yațlubūna dhāli-

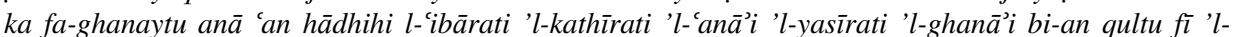
dhāli al-dhu'nūnu nabatun wa-fì 'l-ță'i al-țurthūthu nabatun li-anna 'l-shay'a idhā kāna fu'lūlan fajam'u-hū lā maḥālata fa'ā̄ìlu wa-idhā kāna 'l-jam'u fa'ālīla lam yalzam an yakūna 'l-wāhidu fu'lūlan wah̀da-hü bal qad yakūnu fi lālan wa-fi lìlan wa-fi lālatan wa-fi lìlatan. 
tributes of the genus, e.g., any attribute of an animal; and the singular words dhu'nūn, turthīth behave as the species of the genus, e.g., lion, horse, man. There are at least two aspects to the parallel under scrutiny. In the first place, by interpreting the two plural words dha'ānin and tarāthith as attributes of a genus, and the $b \bar{a} b$ consisting of a plural pattern $f a^{c} \bar{a} l \bar{l} l$ to the genus, this parallel explicitly construes the $b \bar{a} b$ as an entity capable of grouping (cf. the bāb's resemblance to the genus) two words (cf. dha'ānin, taräthìth) on the basis of their shared phonotactic sequence $a \ldots \bar{a} \ldots \bar{l}$ and, what is more relevant here, on the basis of their semantic reference to a major concept, i.e., the sememe [plural] (cf. their plural nature and the equally plural nature of the $b \bar{a} b$ ). It thus becomes evident that the term $b \bar{a} b$ encodes a philosophical taxonomical condition that, except for its phonotactic facet $a \ldots \bar{a} \ldots \bar{l}$, is highly reminiscent of the basic content of the semantic field, as outlined at the very beginning of the first section. Secondly, the parallel drawn by Ibn Sīdah occurs within the broader context of a metalinguistic discussion, in which he also mentions his predecessors, the so-called ahl al-lughah, which include the like of Abū 'Ubayd (d. 224/838). The Andalusian lexicographer explicitly states that the lexicographers preceding him in principle assigned a similar specific technical sense to the term $b \bar{a} b$, i.e., a genus having semantic and phonotactic properties; and yet he blames them for having 'fragmented' this $b \bar{a} b$ into species in their lexicographical practice-a point to which we will return in due course ('ādat abwābuhum li-abwābì shuțūran...akhadhū mahmmūla-hu [i.e., al-bābi] 'alà anwā'in jammatin wa-akhadhtu-hu anā 'alà 'l-jins). In other words, the specific technical sense that Ibn Sīdah assigns to the term $b \bar{a} b$ is at once intergenerational and subject to an intellectual controversy in the Arabic lexicographical tradition, which substantiates the impression that the specific technical sense in question distills a real notion.

In other words, the marked similarity noted above between Ibn Sīdah's $b \bar{a} b$ and the present-day semantic field with respect to their basic descriptive content is even stronger than initially apparent: the former term underpins a fully fledged notion just as the latter does. On the whole, the passage of the Introduction to the Muhkam analysed thus far can serve as a locus probans for the hypothesis put forward by Haywood, Cabanelas and Baalbaki, which regards $b \bar{a} b$ as an early manifestation of the modern notion of semantic field within the context of the Arabic linguistic tradition, with the caveat that this manifestation is richer than its modern Western counterpart, in that it provides the major concept also with a phonotactic description. Having ascertained that a notion highly reminiscent of that of semantic field underlies the term $b \bar{a} b$ in Ibn Sīdah's lexicographical work, we can proceed to examine more closely to which version of the modern Western notion of semantic field Ibn Sīdah's notion of $b \bar{a} b$ corresponds - whether the 'historical-comparative' or the 'stylistic' version.

To this end, two passages drawn from the Introduction to the Mukhașșaș are particularly worth quoting. In view of the fact that the Mukhașs as makes extensive use of the notion of $b \bar{a} b$ as a compositive unit, as discussed in the previous section, the linguistic considerations that Ibn Sīdah formulates in these passages to illustrate this dictionary plausibly carry over to the notion of $b \bar{a} b$ itself. The first passage states that "in the souls, there are meanings that reside in them and can be grasped by thought (fí 'l-nufüsi min-a ' l-ma'ānī ' $l$ $q \bar{a}$ 'imati fi-hā 'l-mudrakati bi'l-fikrah)," ${ }^{62}$ with a perspicuous reference to a conception of

62 IBN SīDAH, Mukhașșaș, i: 2. 
meaning that considers it as pre-existing in the dimension of ideas, thought or the like, i.e., a positive conception of meaning. In the second passage, Ibn Sĩdah explicitly asserts that the Mukhașsas is "a dictionary that I arranged thematically since I saw it as more useful to the educated and literate person, to the fluently eloquent person, to the fecund orator and to the outstanding and sophisticated poet (kitāban ada'u-hu mubawwaban hìna ra'aytu-hu ajdà 'alà 'l-fașịhi 'l-midrahi wa'l-balīghi 'l-mufawwahi wa'l-khațībi 'l-mișqa'i wa'l-shā'iri 'l-majidi 'l-midqa)." ${ }^{63}$ Briefly, these two passages can be adduced as loci probantes for better defining the notion of semantic field encoded in the term $b \bar{a} b$ as semantically positive and stylistics-oriented.

To this, we might add that the passage of the Introduction to the Muhkam reproduced immediately above clearly testifies to Ibn Sīdah's use of the notion of $b \bar{a} b$ as a useful tool to preserve the huge amount of (word) meanings transmitted by his predecessors, e.g., Abū 'Ubayd (al-muhäafazati 'alà jam 'i 'l-ma'ānī 'l-kathīrati [...] fa-kam bäbin fì kutubi ahli 'llughati ațālu-hu). Hence, in the passage under scrutiny, Ibn Sīdah works out a notion of $b \bar{a} b$ which describes an archaic variety of Arabic to the exclusion of subsequent language stages and other languages - technically speaking, he works out a synchronic and intralinguistic notion of $b \bar{a} b$. It is a matter of wide consensus among scholars that the main reason causing Arabic lexicographers, Ibn Sīdah included, to focus on this archaic variety of Arabic is their interest in the Bedouin civilization during the rise of Islam. ${ }^{64}$ In this sense, Ibn Sīdah's use of the notion of $b \bar{a} b$ with the aim of transmitting both an archaic stage of Arabic and its universe of discourse causes the notion in question to also become cultureoriented.

In the same passage, the Andalusian lexicographer also points out that he has opted for a simplified arrangement of the huge amount of (word) meanings he has collected from his predecessors, which deliberately omits the mention of any single predictable plural form

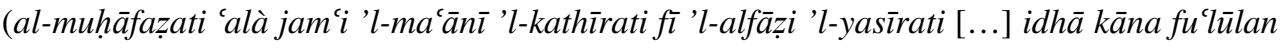
fa-jam'u-hu lā mahălata fa'ālill). As alluded to above, Ibn Sīdah formulates this assertion in philosophical taxonomical terms. There is no need to explicitly and analytically mention a given attribute for each of the species lion, horse, man, so his argument goes, given that such an attribute can be deduced from their genus animal; similarly, there is no need to explicitly and analytically mention the plural words dha'ānin, taräthìth for each of the singular words dhu'nün, turthūth, given that such a plural word can be deduced from their

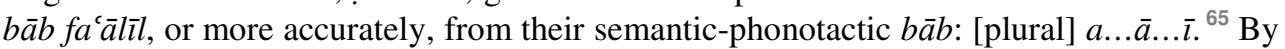
resorting to a simplified arrangement of this sort, the Andalusian lexicographer establishes his methodological distance from his predecessors, who, on the contrary, explicitly and analytically mention virtually every plural word, e.g., dha'ānīn, taräthìth, for virtually

63 IBN SīDAH, Mukhașşaș, i: 10. See also CABANELAS 1961: 19 for a Spanish translation of this passage.

64 See, e.g., BAALBAKI 2014: 6, 409.

65 In passing, this passage brings to light a notion of $b \bar{a} b$ which cannot be mistaken for a compositive unit. In the Muhkam the $b \bar{a} b$ acts, so to speak, in absentia, since its role is making words (specifically the plural words) not recorded in this lexicographical work (in modern linguistics, this kind of $b \bar{a} b$ would therefore be regarded as a sort of default rule). The role of a compositive unit is precisely the opposite: effectively, what the bāb does in the Mukhașsas is, on the contrary, to make words recorded in it.

jais • 17 (2017): 415-433 
every Arabic singular word, e.g., dhu'nūn, țurthūth. In keeping with the philosophical taxonomical metaphor, the Andalusian lexicographer rejects the methods of his predecessors, who explicitly and analytically mention a given attribute for each species, thereby fragmenting the semantic-phonotactic notion of $b \bar{a} b$. Instead, Ibn Sīdah subsumes as many plural words as possible, e.g., dha'āninn, țarāthīth, under the common meaning [plural] and phonotactic sequence (e.g., $a \ldots . . \bar{a} . . . \bar{l})$, thereby consciously rejecting the separate or 'atomistic' treatment of any single plural word in favor of their global treatment. In this sense, he assigns a holistic meaning to $b \bar{a} b$. To summarize, the passage of the Introduction to the Muhkam that we have discussed at length in the foregoing passage can plausibly be adduced as a locus probans for a better definition of the notion of semantic field encoded in the term $b \bar{a} b$ as synchronic, intralinguistic, culture-oriented and holistic.

These features of the notion of $b \bar{a} b$, when coupled with the features emerging from an attentive reading of the Introduction to the Mukhașsaș-notably its being semantically positive and stylistics-oriented-plausibly show that this notion is almost identical to the 'stylistic' version of semantic field or, more concretely, to Roget's notion of class. This state of affairs can easily be gleaned from a comparison between the features of Ibn Sīdah's notion of $b \bar{a} b$ and those of Roget's notion of class, as schematized in Table 2 (identical features in italics). Remarkably, Cabanelas intuitively suggests a broad parallel between Ibn Sīdah's Mukhașsas and Roget's thesaurus, anticipating the narrow parallel between Ibn Sīdah's notion of $b \bar{a} b$ and Roget's notion of class, which we have just established feature by feature. ${ }^{66}$

\begin{tabular}{lll}
\hline Version & 'Stylistic' & Arabic Lexic. Tradition \\
Example & Class & Bāb \\
Main proponent(s) & Roget & Ibn Sīdah \\
Features & Semantically holistic & Semantically holistic \\
& Semantically positive & Semantically positive \\
& Intralinguistic & Intralinguistic \\
& Synchronic & Synchronic \\
& Culture-oriented & Culture-oriented \\
& Stylistics-oriented & Stylistics-oriented \\
& - & Phonotactics \\
\hline
\end{tabular}

Table 2 - The Notions of Class and Bāb

The discussion thus far therefore corroborates an analysis of the term $b \bar{a} b$ along the lines of the modern Western notion of semantic field, and of the latter's 'stylistic version' in particular, by means of a textual research that takes as its starting point the terminological

66 CABAnelas 1961: 30-1. 
relationship between $b \bar{a} b$ and jins-in essence, one of synonymy. In this connection, it seems convenient to touch upon two other terminological relationships first observed by Cabanelas, which can further corroborate an analysis of this kind. The first terminological relationship holds between $b \bar{a} b$ and fașl and appears to be one of antonymy. In the Mukhașas Ibn Sīdah sometimes, though not constantly, uses the term faṣl to group words with no semantic reference to a major concept ("A veces alguno de los capítulos aparece independiente e incluye varios faṣl no agrupados por un tema específico"), ${ }^{67}$ in contrast to $b \bar{a} b$, which does exactly the opposite, especially in light of the analysis carried out in this paper.

The second terminological relationship occurs twice in the Introduction to the Mukhașaș. In one case, it involves the terminological pair musammàn 'nominal meaning' / asma 'nouns' and, in the other, the terminological pair mawșūf 'adjectival meaning' / awșāf 'nouns' (fa-inna-hū idhā kānat lil-musammà asmā’un kathīratun wa-lil-mawșūfi awșāfun 'adīdah). ${ }^{68}$ In both cases, it more abstractly involves many words (asmä or awșaff) and the major concept semantically referred to (musammàn or mawșüf), which constitute the two basic ingredients of the notion of semantic field as illustrated at the beginning of this paper. In this passage, however, Ibn Sīdah does not directly link such ingredients to the term $b \bar{a} b$ to create a relationship of inclusion, in the sense that he does not group the $a s m \vec{a}$ ) or the $a w s ̦ \bar{a} f$ under the term $b \bar{a} b$ on the basis of their semantic reference to a musammàn or to a mawșüf, contrary to his approach in his Introduction to the Muhkam, in which he groups the words dha'ānin, țarāthith under the term $b \bar{a} b$ on the basis of their semantic reference to the sememe [plural]. ${ }^{69}$ Rather, the relationship of inclusion created by Ibn Sīdah in the case of the terminological pairs musammàn / $a s m \bar{a}$ ' and mawșüf / awșâf with respect to bāb is very loose. In fact a few lines above he simply says that the poet or the orator who is in need of many words (asma $\bar{a}^{\text {’ }}$ or $a w s \underline{a} f$ ) and of the major concept semantically referred to (musammàn or mawșüf) will find them within a mubawwab 'a dictionary arranged in bābs', a term etymologically related to $b \bar{a} b$, without stating that this poet or orator will find them in a dedicated bāb (kitāban aḍ' 'u-hu mubawwaban ḥina ra'aytu-hu ajdà 'alà 'l-fașīhi 'lmidrahi wa'l-balīghi 'l-mufawwahi wa'l-khațībi 'l-misqqa'i wa'l-shāiri 'l-majīdi 'l-midqa'i fa-inna-hu idhā kānat lil-musammà asmā'un kathīratun wa-lil-mawșūfi awșāfun 'adīdatun tanaqqà 'l-khațību wa'l-shā'iru min-hā mā shäa). ${ }^{70}$ Nonetheless, Ibn Sīdah establishes a narrower relationship of inclusion, which the terminological pairs musammàn / asma $\vec{a}^{\prime}$ and mawșüf / awșāf entertain with respect to the term bustān 'garden' when, in the passage under scrutiny, he metaphorically conceives of many words all referring to a major concept as the different species of herbs growing in gardens ('alà mithāli mā najidu-hū nahnnu fí 'ljawāhiri 'l-maḥsūsati ka'l-basātīni tajma'u anwā'a 'l-rayāhīnn). ${ }^{71}$ In sum, the terminological pairs musammàn / asmä and mawșüf / awșāf entertain a relationship of inclusion both with respect to the term bustān and-albeit to a lesser degree-with respect to the term $b \bar{a} b$ (as implied by its derived form mubawwab). This state of affairs reveals a feature of the

67 CABANELAS 1961: 23.

68 IBN SİDAH, Mukhașșaș, i: 10. See also CABANELAS 1961: 19 for a Spanish translation of this passage.

69 See the beginning of this Section.

70 IBN SĪDAH, Mukhașșaș, i: 10. See also CABANELAS 1961: 19 for a Spanish translation of this passage.

71 Dto.

jحis • 17 (2017): 415-433 
notion of $b \bar{a} b$, which the latter does not share with the Rogetian notion of class, notably a metaphorical conception in terms of a garden.

The next section tackles the issue of the similarities and differences between the notion of $b \bar{a} b$ and the modern Western notion of semantic field from a broader perspective, offering the main conclusions.

\section{Conclusions}

It seems safe to maintain that the modern Western notion of semantic field has an almost identical counterpart in Arabic linguistic thought, provided that both the Western notion and its medieval Arabic counterpart are accurately defined, respectively, as Roget's classwhat has also been labeled here as a 'stylistic' version of semantic field—and Ibn Sīdah's $b \bar{a} b$. The correspondence between Roget's class and Ibn Sīdah's $b \bar{a} b$ is almost total, in the sense that, as schematized in Table 3, the latter notion possesses all the features of the former, plus two additional features, which consist of a phonotactic aspect and a metaphorical conception in terms of a garden or, generally speaking, of an area of land (cf. the key term bustān 'garden'). This metaphorical conception is a feature that we can also observe in Ipsen's Bedeutungsfeld-labeled here as a 'historical-comparative' version of semantic field - in which the key term -feld or 'field' equally denotes an area of land. However, the resulting parallel between Ibn Sīdah's bāb and Ipsen's Bedeutungsfeld is certainly weak, as it is confined to this single feature, as schematized in Table 3. Finally, Ibn Sīdah's bāb is semantically holistic and culture-oriented to the same extent as both Roget's class and Ipsen's Bedeutungsfeld, as is apparent, again, from Table 3 (see next page).

In this case too, however, the resulting parallel is rather weak, being confined to two features only. Hence, it should be stressed once more that the presence of a medieval Arabic counterpart of the modern Western notion of semantic field substantially mirrors the latter's 'stylistic' version. In this connection, the question may arise as to why the 'stylistic' version of semantic field, i.e., Roget's notion of class, and its medieval Arabic counterpart, i.e., Ibn Sīdah's notion of $b \bar{a} b$, resemble each other so strongly. In principle, two tentative answers can be suggested. The first tentative answer is that the very strong resemblance in question is the result of convergence-the coincidence favored by similar factors, such as a similar environment, similar cognitive needs, etc. ${ }^{72}$ The second tentative answer relies upon Roget's admission of having been influenced by Sanskrit lexicography, as pointed out above. Interestingly, some Arabists hypothesize a similar scenario for the beginnings of Arabic lexicographical tradition: ${ }^{73}$ they admit the possibility that al-Khalis borrowed the idea of arranging the alphabet letters according to their points of articulation in the Kitāb al-'Ayn from Sanskrit lexicography, although they do not exclude a priori the possibility that this idea is original to him (in which case the similarity between al-Khalil's Kitāb al'Ayn and Sanskrit lexicography would be due to convergence).

72 See ANTTILA 1989: 390, 394

73 See HAYWOOD 1960: 37-8, BAALBAKI 2014: 54 and references therein. 


\begin{tabular}{|c|c|c|c|}
\hline Version & 'Historical-comparative' & 'Stylistic' & Arabic Lexic. Trad. \\
\hline Example & $\begin{array}{l}\text { Innere Sprachform, Bedeu- } \\
\text { tungsfeld }\end{array}$ & Class & Bāb \\
\hline $\begin{array}{l}\text { Main pro- } \\
\text { ponent(s) }\end{array}$ & Humboldt, Ipsen, Trier & Roget & Ibn Sīdah \\
\hline \multirow[t]{8}{*}{ Features } & Semantically holistic & Semantically holistic & Semantically holistic \\
\hline & Semantically negative & Semantically positive & Semantically positive \\
\hline & Interlinguistic & Intralinguistic & Intralinguistic \\
\hline & Diachronic & Synchronic & Synchronic \\
\hline & Culture-oriented & Culture-oriented & Culture-oriented \\
\hline & - & Stylistics-oriented & Stylistics-oriented \\
\hline & - & - & Phonotactics \\
\hline & Metaphor: area of land & - & $\begin{array}{l}\text { Metaphor: area of } \\
\quad \text { land }\end{array}$ \\
\hline
\end{tabular}

\section{Table 3 - The Modern Western Notion of Semantic Field and Its Medieval Arabic Counterpart}

Based on this line of reasoning, one may venture to speculate that the explanation for the very strong resemblance between Ibn Sīdah's notion of $b \bar{a} b$ and Roget's notion of class lies in a genetic relationship, rather than a convergence. According to this hypothesis, both notions originate from a common, remote ancestor to be identified with Sanskrit lexicography and the various shared features are accordingly the result of indirect filiation (in any case, the assumption of a direct filiation of either notion from the other seems highly questionable). As is the case for the alphabetical order adopted by al-Khalīl in his Kitāb al- 'Ayn, at the present research stage it is not possible to favor the hypothesis of convergence over that of genetic relationship, or vice versa, in order to explain the very strong similarities existing between the 'stylistic' version of the modern Western notion of semantic field, e.g., Roget's notion of class, and its medieval Arabic counterpart, as instantiated by Ibn Sīdah's notion of $b \bar{a} b$. However, it seems safe to maintain that, on philological and textual grounds, the hypothesis of genetic relationship is far harder to demonstrate than that of convergence. 


\section{Bibliography}

ANTtILA, R. 1989. Historical and Comparative Linguistics. Amsterdam: Benjamins.

BAALBAKI, R. 2014. The Arabic Lexicographical Tradition. Leiden/Boston: Brill.

Cabanelas, D. 1961. "El Mujașșaș de Ibn Sīda de Murcia, primer diccionario de ideas afines en el Occidente musulmán”. Miscelánea de estudios árabes y hebraicos. Sección Árabe-Islam, 10: 7-36.

Clarke, D. / Nerlich, B. 2000. "Semantic Fields and Frames: Historical Explorations of the Interface between Language, Action and Cognition". Journal of Pragmatics, 32: 125-50.

FRIEDRICH, J. (ed.). 1924. Stand und Aufgaben der Sprachwissenschaft. Festschrift für Wilhelm Streitberg. Heidelberg: Winter.

GeERAERTS, D. 2010. Theories of Lexical Semantics. Oxford: Oxford University Press.

Haywood, J. 1990. Arabic Lexicography: Its History, and Its Place in the General History of Lexicography. Leiden/Boston: Brill.

Hüllen, W. 2003. A History of Roget's Thesaurus: Origins, Development, and Design. Oxford: Oxford University Press.

IBN SīDAH, Abū 'l-Ḥasan 'Alī b. Ismāçîl. 1898. Al-Mukhașṣaș / ed. M. 'ABDUH [et al.]. al-Qāhirah: alBūlāq.

— . 2000. Al-Muḥkam wa'l-Muḥịt al-A 'ẓam / ed. 'A. Ḥ. HindĀwī. Bayrūt: Dār al-Kutub al-'Ilmiyya.

IPSEN, G. 1924. “Der alte Orient und die Indogermanen”. In FRIEDRICH (ed.) 1924: 200-37.

MALKIEL, Y. 1993. Etymology. Cambridge: Cambridge University Press.

Moscati, S. 1958. Le antiche divinità semitiche. Roma: Centro di Studi Semitici.

OwENS, J. 1990. Early Arabic Grammatical Theory: Heterogeneity and Standardization. Amsterdam: Benjamins.

PELED, Y. 1999. "Aspects of the Use of Grammatical Terminology in Medieval Arabic Grammatical Tradition”. In SUlEIMAN (ed.) 1999: 50-85.

PISANI, V. 1938. "Paleontologia linguistica: Note e critiche metodologiche". Annali della Facoltà di Lettere e Filosofia della Regia Università di Cagliari, 9: 1-54.

Roget, P. M. 1852. Thesaurus of English Words and Phrases, Classified and Arranged so as to Facilitate the Expression of Ideas and Assist in Literary Compositions. London: Longman, Brown, Green, and Longmans.

al-ṬĀLIBĪ, M. 1956. Al-Mukhașșaș li-Ibn Sīdah. Dirāsah - dalīl. Tūnis: al-Maṭaa'a al-'așriyya.

TRIER, J. 1931. Der deutsche Wortschatz im Sinnbezirk des Verstandes: Die Geschichte eines sprachlichen Feldes. Vol. I: Von den Anfängen bis zum Beginn des 13. Jhdts. Heidelberg: Winter.

SulEIMAN, Y. (ed.). 1999. Arabic Grammar and Linguistics. London/New York: Routledge.

vON HumboldT, W. 1836. Über die Verschiedenheit des menschlichen Sprachbaues und ihren Einfluss auf die geistige Entwickelung des Menschengeschlechts. Berlin: Dümmler.

(C) Francesco Grande, Università Ca' Foscari, Venice, Italy 4 francesco.grande@unive.it 